DOI: http://dx.doi.org/10.5007/2175-7941.2014v31n1p7

\title{
Pensando a natureza da ciência a partir de atividades experimentais investigativas numa escola de formação profissional ${ }^{+*}$
}

Clarice Parreira Senra

Colégio Militar

Juiz de Fora - MG

Marco Braga

CEFET-RJ

Rio de Janeiro - RJ

\section{Resumo}

A partir de uma concepção de atividade experimental aberta (BORGES, 2002), procurou-se formar um grupo de investigação com alunos de um curso de formação profissional de nível médio (denominada célula de inovação) para desenvolver um projeto de pesquisa técnico-científico. O projeto proposto aos alunos foi o da construção de um coletor solar para aquecimento de água utilizando materiais descartáveis com baixo poder de reciclagem. Pretendeu-se investigar as reflexões empreendidas pelos alunos ao longo dessa atividade sobre a atividade da pesquisa científica e tecnológica e como um ambiente experimental aberto pode facilitar o surgimento da criatividade. A pesquisa se utilizou de diversas formas de coleta de dados sobre o processo educacional, desde a análise das anotações feitas pelo professor orientador da célula durante as atividades até a realização de um grupo focal ao término do projeto.

\footnotetext{
Thinking the Nature of Science and Technology from experimental investigative activities in a Professional Training School

* Recebido: junho de 2013. Aceito: setembro de 2013.
} 
Palavras-chave: Natureza da Ciência, experimentação. Grupos de trabalho. Projetos. Atividades experimentais investigativas.

\begin{abstract}
Based on an experimental open design activity (BORGES, 2002), we tried to form a research group with mid-level students of a Professional Training School (called innovation cell) to develop a technical-scientific research project. The students proposed project was the construction of a solar collector for heating water using disposable materials with low power recycling. It was intended to investigate the reflections undertaken by the students throughout this activity on the Nature of Science, Technology and Nature as an experimental open environment can facilitate the emergence of creativity. The survey was used in various ways to collect data on the educational process, from analysis of notes made by the teacher guiding the cell during the activities until the completion conducting a focus group at the end of the project.
\end{abstract}

Keywords: Nature of Science. Trial. Workgroups. Projects. Experimental investigative activities

\title{
I. Introdução
}

Vivemos em uma sociedade onde as criações científicas e tecnológicas crescem a cada dia. No mundo moderno, além de ser necessário ter um conhecimento bem fundamentado dos conteúdos das ciências, é de extrema importância que os alunos tenham também uma compreensão sobre a própria Ciência. Portanto, um bom curso científico deve ter uma preocupação de mesclar conteúdos científicos e elementos de metaciência, ou como tem sido denominado em diversos estudos da área de ensino, de Natureza da Ciência ( $\mathrm{NdC}$ ). Embora se possa questionar a existência de uma natureza da ciência (IRZIK; NOLA, 2011), pode-se dizer que tais estudos abarcam um amplo leque de problemas relacionados à construção do conhecimento científico. Este termo passou a ser bastante difundido nos meios educacionais após a edição do documento base do Projeto 2061 nos Estados Unidos da América (AAAS, 1989). 
"A natureza da ciência” inclui a visão de mundo da ciência, os métodos de investigação científica e a natureza do empreendimento científico ${ }^{I}$ (AAAS, 1989)

No mesmo documento existe uma referência à importância da introdução de questões ligadas à Natureza da Tecnologia (NdT), que trataria de uma reflexão sobre os processos tecnológicos. A construção da cidadania passa hoje necessariamente por uma compreensão mínima de questões ligadas tanto à ciência como à tecnologia (AULER; DELIZOICOV, 2001; PRAIA; GIL PÉREZ; VILCHES, 2007). Para alunos de cursos de formação profissional de nível médio essas duas questões são de grande importância.

O ensino que atualmente é praticado nas escolas está longe de possibilitar ao aluno uma reflexão sobre o processo de construção do conhecimento científico. $\mathrm{O}$ que se pode encontrar nos currículos sobre esse tema limita-se à apresentação de um suposto "método científico", apresentado normalmente como um protocolo seguro para a obtenção de um conhecimento verdadeiro e objetivo.

O ensino real, praticado nas escolas, centra-se muito mais na aprendizagem de conteúdos científicos prontos e acabados do que nos processos de sua construção. Sem querer negá-los, acaba-se levando os alunos a acreditarem que em ciência existe uma verdade que é descoberta (não construída) a cada dia por seres superdotados.

Por outro lado, o sistema de avaliação faz com que o aluno estude para fazer provas. Esse sistema de avaliação acaba invertendo o sentido do processo. A avaliação deixa de ser uma verificação da aprendizagem para transformar-se em objetivo da aprendizagem. Toda a aprendizagem fica contaminada por essa inversão. O aluno estuda, não para aprender ou para refletir sobre questões relevantes, mas para fazer provas. $\mathrm{O}$ estudo acaba visando às questões das provas, o que acarreta numa deformação da aprendizagem em função daquilo que se espera encontrar nessas avaliações.

Nesse tipo de ensino, frequentemente denominado de ensino tradicional, o professor é tido como centro do processo, tendo por função apresentar o que é certo ou errado e os caminhos que se deve seguir para dar "respostas certas" na avaliação. A maioria dos alunos coloca o professor como maior responsável pelo processo de aprendizagem e espera passivamente que ele apresente as respostas e soluções para os problemas encontrados.

\footnotetext{
${ }^{1}$ The Nature of Science includes the scientific worldview, scientific methods of inquiry, and the nature of the scientific enterprise.
} 
Qualquer professor que tente quebrar essas regras acaba tendo sua posição questionada. Os alunos, por não entenderem a nova lógica daquilo que está sendo proposto, entram em pânico. A pergunta-chave que espelha melhor essa situação é: como você pretende cobrar isso na prova?

Diversos pesquisadores da área de Ensino de Ciências (BORGES, 2002; ARAÚJO; ABIB, 2003; JULIO; VAZ, 2007; GIL PÉREZ; VALDÉS CASTRO, 1996; HERNANDES; CLEMENT; TERRAZAN, 2002; JULIO; VAZ, 2004) vêm defendendo já há alguns anos o uso de práticas de laboratório como uma das formas de transformar o ensino tradicional. Várias maneiras de organizar as atividades experimentais vêm sendo apresentadas. Alguns desses caminhos podem despertar a curiosidade e interesse dos alunos, além de suscitar discussões e estimular o posicionamento crítico dos alunos. Eles podem ainda orientar a reflexão sobre os resultados e sobre a forma de expressá-los corretamente, permitindo uma reflexão sobre possíveis aplicações relacionadas a situações ou problemas reais e, ainda, favorecer o trabalho em grupo, de extrema importância para a vida profissional.

Entretanto, apesar de todas essas propostas, tanto nas universidades como nas poucas escolas que possuem laboratórios, a utilização de experimentos ainda é feita a partir de práticas fechadas, onde os alunos não conseguem compreender claramente o que estão fazendo, já que estas são acompanhadas por um "receituário", com regras rígidas, que impedem a reflexão e principalmente a criatividade. No campo da Natureza da Ciência, algumas dessas práticas reforçam visões indutivistas da construção do conhecimento científico ou, ao contrário, apresentam a experimentação como uma atividade secundária, servindo apenas para confirmar "descobertas" feitas pela genialidade de cientistas teóricos. É raro ver a experimentação como fonte de uma problematização.

A inquietude com esses problemas fez com que um grupo de pesquisadores procurasse desenvolver práticas experimentais diferenciadas, onde além da aprendizagem de conteúdos científicos se pudesse implementar também uma reflexão sobre a construção do conhecimento científico durante o próprio processo de investigação. A ideia central seria problematizar o processo de construção do conhecimento científico a partir do envolvimento dos estudantes num processo de investigação e de discussões sobre a prática científica inserida no contexto social. Nesse caso a Natureza da Ciência seria tratada a partir de uma dupla abordagem, tanto implícita (investigação) como explícita (discussão sobre). Abd-El-Khalick (2012) defende que o simples envolvimento não possibilita a compreensão da atividade científica em sua totalidade. Existiria a necessidade de reflexão e problematização das situações vivenciadas. Para tanto, procurou-se propor aos alunos 
uma investigação sobre um problema concreto em paralelo com discussões sobre as relações entre ciência e sociedade.

A utilização de atividades investigativas, normalmente fundamentadas na utilização de questões abertas ou problematizadoras, permite criar situações que tendem a propiciar boas condições para que os alunos reflitam sobre a atividade científica e tecnológica. Além disso, permite também o exercício da criatividade (ARAÚJO; ABIB, 2003), pois os alunos são frequentemente confrontados com problemas concretos que necessitam de soluções para que a atividade continue a ser encaminhada.

Diante da importância do aluno vivenciar e propor soluções para problemas reais no âmbito escolar e refletindo em torno de propostas pedagógicas destinadas a criar situações de aprendizagem mais dinâmicas e efetivas, decidiu-se trabalhar com a proposta pedagógica dos projetos de pesquisa (HERNÁNDEZ; VENTURA, 1998; MARTINS, 2009; HERNÁNDEZ, 1998). Essa proposta, além de vir ao encontro daquilo que se pretendia em termos de trabalho experimental, permitiu também a possibilidade de inserção de temas controversos no processo de ensino.

\section{Desenvolvimento do Projeto}

Em 2008 foi criada no CEFET/RJ uma rede de aprendizagem, formada por pequenos grupos de alunos, que foram denominadas "Células de Inovação". Nesses grupos os alunos eram envolvidos em problemas reais, discutiam sobre eles e buscavam desenvolver soluções para os mesmos. Cada célula tinha a orientação de um professor externo, diferente daquele que ministrava as aulas formais. Esse professor tinha o papel de dinamizar discussões e coordenar o desenvolvimento do projeto com os alunos. O papel desse professor não era de apresentar algo pronto, uma receita a ser seguida, mas orientá-los a investigar, alimentando-lhes a curiosidade e incentivando a busca de respostas (MARTINS, 2009). As células não pretendiam substituir as aulas, mas ser uma alternativa e um complemento do trabalho formal que visava enriquecer a educação escolar. As atividades eram feitas em períodos alternativos às aulas, já que os alunos da escola faziam disciplinas de Ensino Médio pela manhã e disciplinas técnicas em três dias da semana à tarde. Embora independente, o trabalho procurava dialogar com as disciplinas formais.

Os primeiros passos desse projeto tiveram início em 2010 e constituíramse do acompanhamento, por parte de um dos pesquisadores da equipe, das aulas formais de Física de três turmas da primeira série do Ensino Médio. Esse pesquisador passou a assistir as aulas ministradas pela professora dessas turmas e a obser- 
var o comportamento dos alunos em classe. Esse acompanhamento durou aproximadamente oito semanas, entre fevereiro, março e abril. Dessa forma, já havia certa familiaridade entre esse pesquisador e os alunos quando os trabalhos começaram.

O segundo passo foi marcar uma reunião e apresentar aos alunos o projeto. O pesquisador, que não era professor da escola, fez a proposta de realização de uma investigação científica e tecnológica. A partir daí se apresentaram os voluntários e este pesquisador passou a atuar como uma espécie de professor-orientador dos grupos de investigação. O projeto procuraria discutir alguns problemas ambientais vivenciados por regiões com baixo nível de desenvolvimento econômico, como favelas nas grandes cidades ou regiões rurais distantes e construir um aparato tecnológico de baixo custo visando à solução daqueles problemas.

A partir da inscrição dos alunos interessados, foram constituídas três células (A, B e C). A primeira (A) possuía 8 alunos e era formada por alunos do curso técnico de Mecânica, a segunda (B) possuía 6 alunos de Segurança do Trabalho e Edificações e a terceira (C) contava com 13 alunos do curso de Eletrônica.

No total foram trinta e um encontros, compostos por debates, atividades experimentais, visitas a algumas instituições de pesquisa e a exposições em centros de ciências. Todos os encontros ocorreram fora do horário de aulas, portanto constituiu-se de uma atividade extraclasse. Além desses encontros, também houve uma apresentação do aparato tecnológico construído para a comunidade escolar, durante um evento anual que ocorre na Semana Nacional de Ciência e Tecnologia (SNCT). Esse evento tem um importante caráter motivador. Por ser constituído por trabalhos desenvolvidos pelos alunos da escola durante o ano, todos almejam poder apresentar seus projetos aos visitantes, que são formados pelo conjunto de alunos da instituição, por pesquisadores, por empresários e por alunos de escolas vizinhas.

A tabela abaixo apresenta um breve resumo dos encontros realizados com cada uma das três células.

Tabela 1 - Descrição das atividades propostas no Projeto.

\begin{tabular}{|c|l|}
\hline Encontros & \multicolumn{1}{|c|}{ Atividades } \\
\hline Divulgação & $\begin{array}{l}\text { Apresentação da proposta de trabalho a três turmas de } 1^{\circ} \text { ano do } \\
\text { Ensino Médio }\end{array}$ \\
\hline $1^{\circ}$ & Aplicação do questionário pré-teste \\
\hline $2^{\circ}$ & Tema Controverso: Aquecimento Global e Efeito Estufa \\
\hline $3^{\circ}$ & Tema Controverso: Lixo \\
\hline
\end{tabular}




\begin{tabular}{|c|l|}
\hline $4^{\circ}$ & Tema controverso: Fontes de Energia/Energia Limpa \\
\hline $5^{\circ}$ & Visita: Exposição sobre Energia Nuclear \\
\hline $6^{\circ}$ & Tema controverso: Energia Solar e Eólica \\
\hline $7^{\circ}$ & $\begin{array}{l}\text { Soluções apresentadas pelos alunos/ } \\
\text { Solução escolhida - Aquecedor Solar }\end{array}$ \\
\hline $8^{\circ}$ & $\begin{array}{l}\text { Discussões sobre o procedimento de construção do } \\
\text { Aquecedor Solar }\end{array}$ \\
\hline $9^{\circ}$ & $\begin{array}{l}\text { Discussões sobre o funcionamento do } \\
\text { Aquecedor Solar/Reflexão }\end{array}$ \\
\hline $10^{\circ}$ & Visita: Casa Solar (Energia Solar e Eólica) \\
\hline $11^{\circ}$ ao $26^{\circ}$ & Construção e instalação do aquecedor solar \\
\hline Outubro $^{\circ} 1,22$ e 23$)$ & Expotec: Exposição de Tecnologia durante a SNCT \\
\hline $27^{\circ}$ ao $29^{\circ}$ & Reinstalação do aquecedor e teste da eficiência \\
\hline $30^{\circ}$ & Aplicação do questionário pós-teste \\
\hline $31^{\circ}$ & Reflexão com os alunos sobre o projeto, através do Grupo Focal \\
\hline
\end{tabular}

O objetivo deste artigo será descrever e analisar:

- o processo de discussão e desenvolvimento do artefato tecnológico;

- o processo de investigação gerado pela construção do artefato:

- a interferência causada pela atividade na visão primitiva de ciência e tecnologia dos alunos;

Procurou-se acompanhar o dia a dia desses encontros, registrando as discussões em vídeo. Um diário foi escrito com as observações do pesquisador sobre o comportamento dos alunos durante os encontros e sobre as conversas informais travadas com eles e entre eles.

Essa técnica de investigação aproxima-se daquilo que é considerado uma pesquisa etnográfica (ANDRÉ, 2010; ANDRÉ, 2008; MACEDO, 2006) centrada no relato da experiência em confronto com as falas dos alunos. Os resultados desse conjunto de informações foram discutidos junto ao grupo de pesquisa.

Os encontros iniciaram em Abril e se estenderam até Novembro de 2010. As reuniões eram semanais com duração de uma hora em média.

As observações sobre as visões de $\mathrm{NdC}$ e NdT foram sendo realizadas durante todo o processo, desde as questões discutidas nas primeiras reuniões, envol- 
vendo as diversas temáticas como aquecimento global, energias limpas, destino do lixo, até o trabalho de construção do aparato tecnológico.

Nos $2^{\circ}, 3^{\circ}, 4^{\circ}$ e $6^{\circ}$ encontros, foram discutidos os temas controversos envolvidos no projeto. Para isso, procurou-se utilizar vídeos, reportagens, apresentações em slides. Nesses encontros, foram propostos alguns temas controversos para que os alunos pensassem e discutissem:

1- O que é Aquecimento Global, quais suas causas e consequências?

2- O que são energias alternativas? Elas são poluentes?

3- Existe realmente energia limpa?

4- Existe solução para o problema do lixo? O que os países têm feito?

5- As novas tecnologias poderão salvar o planeta?

Cada encontro foi desenvolvido a partir de uma sequência única. Em primeiro lugar, começava-se com um debate prévio (problematização). Em seguida vinha uma rápida exposição sobre o tema feita pelo professor orientador, para, em seguida, dar continuidade ao debate. Nos encontros indicados na tabela 1 como "tema controverso" $\left(2^{0}, 3^{0}, 4^{0}\right.$ e $\left.6^{0}\right)$ todo o tempo foi dedicado ao debate, onde múltiplas posições foram confrontadas.

Cabe destacar que todas as três células participaram de forma integral ao longo dos primeiros dois meses. A participação desses alunos era voluntária e não acarretava em qualquer benefício em termos de nota. Essa foi uma das condições a ser investigada, já que a cultura das escolas é a de sempre atribuir pontos às atividades. Desejávamos perceber como a retirada desse fator poderia afetar o interesse e a motivação pela aprendizagem.

$\mathrm{O}$ fato das três primeiras semanas serem compostas por debates, fez com que alguns alunos se desinteressassem. Os alunos das Células A e B foram os primeiros a iniciar o processo de desistência. A justificativa da não permanência nos encontros foi o fato de terem notas baixas em algumas disciplinas, inclusive em Física, precisando, assim, se dedicarem mais aos estudos. Outro fator que dificultou bastante a participação dos alunos foi a existência de aulas de disciplinas técnicas no turno da tarde, o que fez com que os encontros de uma das células fossem realizados no intervalo do almoço. A célula $\mathrm{C}$ foi a que demonstrou maior interesse sobre o assunto e permaneceu com todos os alunos no decorrer dos encontros do projeto. Logo, o restante da pesquisa acabou sendo realizada com esta célula.

Durante os debates iniciais foi solicitado ao grupo que apresentasse, ao final dos encontros, propostas de construção de equipamentos que envolvessem os temas trabalhados e que buscassem alguma solução para esses problemas. No $7^{\circ}$ encontro o grupo teve a oportunidade de expor os aparatos que poderiam ser cons- 
truídos para, posteriormente, fazer a escolha do equipamento que mais se enquadrasse à proposta do projeto.

Vários projetos foram apresentados, como um gerador de energia eólica e um aquecedor solar de baixo custo. Os alunos selecionaram o projeto desenvolvido por um engenheiro de Santa Catarina sobre um aquecedor solar feito de materiais de sucata. O baixo custo do projeto e a possibilidade de sua utilização em larga escala por comunidades carentes foi um fator decisivo da escolha. Além disso, os alunos acreditavam ser esse o projeto mais adequado para ser realizado, pois envolvia diversas temáticas discutidas nas reuniões anteriores, como reciclagem direta das principais embalagens utilizadas em nosso cotidiano, como caixas de leite longa vida e garrafas PET (politereftalato de etileno).

\section{O Artefato}

Após a escolha do equipamento, os alunos foram orientados a pesquisar sobre o aquecedor solar escolhido para ser construído. O $8^{\circ}$ encontro, então, foi dedicado a discutir sobre os materiais utilizados na construção e as ferramentas necessárias para isso. Assim, de posse do manual de construção do coletor (ALANO, 2010), os alunos fizeram a lista dos materiais necessários, e a turma se propôs a recolher as garrafas PET e as embalagens de leite. Além disso, eles discutiram sobre onde o aquecedor poderia ser instalado na escola. Muitos sugeriram a instalação nos vestiários e pediram ao professor orientador que negociasse essa instalação junto à direção da escola.

Essa discussão trouxe à tona um dos aspectos da Natureza da Ciência e da Natureza da Tecnologia. Procurou-se colocar o seguinte problema para eles:

"O que faremos se o aquecedor for construído e instalado no vestiário e, posteriormente, apresentar um defeito ou não funcionar?".

Os alunos não percebiam a necessidade de um teste inicial, a fim de avaliar o funcionamento do aparato e fazer as possíveis modificações. Nesse momento eles foram alertados sobre uma etapa fundamental do trabalho técnico, que é a construção de protótipos. Os protótipos serviriam para testes em pequena escala da funcionalidade do artefato. Além disso, antes da execução de um projeto maior, seria necessário testar a eficiência do coletor. Essa palavra tem um significado bastante específico na tecnologia, pois envolve, além de questões técnicas, também uma avaliação do custo do projeto, determinando assim uma relação custo/benefício. Essas são questões de NdT (AAAS, 1989) com as quais os alunos nunca haviam sido confrontados apesar de estudaram numa escola técnica. 
Vale destacar que, mesmo o coletor não sendo uma criação dos alunos, esperava-se que durante o processo de sua montagem eles fossem sugerindo aperfeiçoamentos, já que a ideia não era simplesmente reproduzir e sim testar e reinventar, processo que incluiria elementos ligados à inovação. Esse ponto inseria-se numa outra dimensão do trabalho que visava verificar se o ato de inovar pode ser aprendido quando oferecidas condições para isso.

No $9^{\circ}$ encontro, já durante a construção do artefato, foram colocadas algumas questões para que os alunos pudessem fazer uma reflexão sobre o projeto, pois se percebeu que, naquele momento, apesar das discussões iniciais, o processo de construção estava sendo desenvolvido sem muita reflexão sobre seu contexto. Pouco entendimento se tinha sobre o funcionamento, a construção do aquecedor, sobre sua utilidade e sua relação com o projeto como um todo. Para tanto, pediu-se que cada aluno fizesse um resumo sobre os encontros anteriores, destacando o que puderam aprender e se gostariam de esclarecimento sobre algum tema. Relembramos, ainda, a questão inicial lançada sobre a construção de um equipamento que englobasse grande parte das questões envolvidas no projeto e pedimos que justificassem o porquê da escolha do aquecedor solar ecológico, destacando quais os benefícios desse equipamento. Ao final, pediu-se que pesquisassem também sobre o funcionamento de um aquecedor solar industrial em comparação com o ecológico (a base de garrafas PET).

Para dar continuidade aos debates sobre Natureza da Ciência e Natureza da Tecnologia, procuramos agendar a visita a um centro de pesquisas em tecnologia. Escolhemos a Casa Solar Eficiente, situada nas instalações do CEPEL (Centro de Pesquisas de Energia Elétrica) da ELETROBRÁS, pois já havíamos citado sua existência nos debates iniciais. Assim, o $10^{\circ}$ encontro foi a visita à Casa Solar Eficiente. Na visita, os alunos puderam ver de perto o funcionamento de um aquecedor solar e de uma placa com células fotovoltaicas. Esse fato contribuiu em muito para o esclarecimento sobre a diferença entre ambos, já que ainda havia algumas dúvidas a esse respeito. Além disso, lá puderam conhecer geradores de energia eólica e o sistema de baterias utilizado na casa para armazenar a energia solar.

Durante a visita, os alunos conversaram sobre o projeto e a construção do aquecedor com um pesquisador do CEPEL. Ele procurou discutir com eles alguns aspectos relacionados à construção do aparato. Sempre na tentativa de problematiza-los a respeito da construção.

A partir daí começou a construção do aquecedor solar que durou do $11^{\circ}$ ao $26^{\circ}$ encontro. Durante as conversas, o grupo chegou à conclusão da necessidade de um registro desse processo, o que facilitaria a etapa final do projeto que seria a apresentação aos demais alunos da instituição e à comunidade. Então, decidiram 
construir um blog ${ }^{2}$ em que, a cada encontro, o grupo registraria as etapas da construção e as dúvidas surgidas, além de ser um meio de divulgação do projeto de um modo geral.

No processo de construção, eles juntaram e selecionaram os materiais recicláveis - garrafas PET e caixas de leite longa vida. Nessa etapa, eles perceberam outra questão referente à tecnologia. Para uma montagem mais eficiente havia a necessidade de se padronizar as garrafas. Isso possibilitaria um melhor encaixe e facilitaria a manutenção a posteriori.

\section{Conteúdos científicos aprendidos através do coletor}

Uma das questões com as quais os pesquisadores necessitavam se defrontar era em relação aos conteúdos, habilidades e competências que seriam aprendidos durante o processo. Para além das questões relativas à NdC e a NdT, que estariam inclusas nas competências e habilidades, existiam também conteúdos científicos que deveriam entrar no processo. Seria muito difícil perceber o nível de aprendizagem desses conteúdos e quais seriam os conteúdos envolvidos, já que a dinâmica do processo não permitia uma seleção e uma avaliação mais aprofundadas. Portanto, decidiu-se fazer um inventário de alguns itens que foram sendo percebidos durante as falas e ações dos alunos nas células.

\section{Questões ambientais}

As primeiras questões referiam-se às questões ambientais. A problematização inicial, que foi de certa forma rejeitada pelas células A e B, permitiu aos alunos da célula $\mathrm{C}$ compreender melhor as inter-relações entre diversos problemas que assistiam diariamente na TV e que nunca tiveram espaço de para discutir e aprofundar. A questão do uso de derivados do petróleo na produção de plásticos e sua impossibilidade em ser reabsorvido pela natureza foi uma das questões chave. O que fazer com estes produtos depois de usados? A ideia de se construir um coletor solar usando garrafas PET visava dois objetivos básicos: o primeiro criar um sistema de utilização de energia barata como a solar no aquecimento de água e outro na finalidade dada às garrafas após seu uso. Todas essas questões foram percebidas pelo grupo durante os encontros e expressadas ao professor na forma de alguma perplexidade.

\footnotetext{
${ }^{2}$ Todo o processo de construção do aquecedor solar pode ser visto em: $<$ http://projetoaquecedorsolar-cefet.blogspot.com/>.
} 


\section{Termodinâmica}

Durante a montagem do aparato surgiram algumas questões relativas aos conteúdos de Física que necessitaram ser investigadas. Apesar de dividirmos aqui para efeito de exposição do processo, os conteúdos foram tratados de forma interligada.

Ao recolherem as garrafas PET, os alunos perceberam que nem todas eram incolores. Muitas das garrafas coletadas eram verdes. Surgiu, então, a pergunta: A cor da garrafa tem algum efeito sobre o resultado do experimento?

Ao estudarem o funcionamento da garrafa, como unidade de aquecimento, eles perceberam que havia necessidade de penetração de radiação no interior da garrafa. A radiação visível seria filtrada pela superfície da garrafa verde. Logo, para maior eficiência do coletor seria necessário utilizar as transparentes.

No passo seguinte, os alunos decidiram construir um protótipo contendo apenas uma placa, com vinte e cinco garrafas PET. Para isso, deveriam adaptar uma caixa d'água menor, já que o painel aqueceria um volume menor de água. Sugeriram, assim, utilizar uma caixa de isopor de 50 litros que ajudaria a manter a água aquecida por mais tempo. Esse passo já demonstrou o entendimento da necessidade de testar um protótipo antes de realizar um gasto maior de recursos sem saber se o projeto estava sendo bem encaminhado.

Uma segunda questão foi colocada por um aluno. Ao ler o manual de montagem e procurar entender o funcionamento do termossifão, ele perguntou como a água iria subir da parte inferior da placa para a superior, onde havia a entrada para a caixa d'água. O grupo procurou explicar a partir da questão da diferença de densidade da água fria e da água quente. Ele aceitou, mas permaneceu incrédulo, mantendo-se em silêncio em relação ao fato. Somente após ver o sistema funcionando se convenceu de que seria possível e revelou aos colegas sua incredulidade após a explicação. Este fato ilustra bem como na maioria das vezes os conceitos são aceitos por conveniência da avaliação. Ele já conhecia a explicação dada desde o ensino fundamental. Entretanto, só depois de ver o fenômeno sua compreensão se completou.

A terceira questão que causou dúvidas referia-se à pintura das caixas de leite com tinta preta fosca. O manual aconselhava a pintar as caixas de preto. Alguns alunos levantaram a hipótese de que se a face fosse deixada na forma original, prateada, haveria maior absorção de calor pelo cano, já que a caixa refletiria a luz. O professor orientador envolvido com a célula procurou não dar respostas. Os alunos já tinham lido alguma coisa sobre a face preta absorver maior quantidade de 
calor que a branca. Entretanto, nunca haviam lido nada sobre a emissão de calor e nem se deparado com a diferença entre a face negra e a prateada.

O professor orientador procurou discutir com o grupo a necessidade de testar a hipótese levantada. Dois alunos sugeriram a construção de um segundo protótipo utilizando a parte prateada existente no interior das caixas de leite e de se medir as temperaturas nas duas situações.

Como só havia uma caixa d'água de isopor, eles decidiram utilizar um galão de 20 litros de água. Mesmo percebendo que a diferença entre as caixas poderia trazer problemas para a investigação, o professor orientador decidiu não problematiza-los ainda naquele momento.

Esse fato refletia outro ponto referente aos métodos de coleta de dados experimentais. Para perceber se um fator é realmente o causador da diferença de resultados, tem-se que garantir que todos os outros permaneçam inalterados. $\mathrm{O}$ fato de utilizar duas caixas, uma de isopor e outra de plástico, traria uma clara diferença nos resultados devido ao não isolamento térmico da água contida no galão. Esse fato, que aos olhos de quem conhece a metodologia experimental parece óbvio, só foi percebido pelos alunos no desenvolvimento do projeto.

Nas semanas seguintes, foi realizado todo o processo de montagem do equipamento. O professor orientador procurava questionar sobre o porquê de todos os procedimentos evitando que a montagem fosse ato meramente mecânico. Assim, foram feitos questionamentos, como por exemplo:

1- Por que pintar os canos de preto?

2- Por que vedar as garrafas?

3- Por que não usar cola PVC na parte inferior do painel (como sugerido no manual)?

4- Como ocorre a circulação da água sem o uso de uma bomba e onde entrava o efeito estufa no funcionamento do aquecedor.

Dessa forma, os alunos sempre foram levados a refletir sobre o trabalho executado. O professor orientador nunca fornecia a resposta imediata, mas colocando-os para pensar, pesquisar e refletir durante todo o processo. Como eram da primeira série e a Termodinâmica só seria apresentada na segunda série, eles tiveram que desfazer muitas dúvidas através de pesquisas em livros, na internet e em consultas a professores.

\section{Eletricidade e eletrônica}

A questão da medição de temperatura da água nas caixas consistiu de outro tópico de aprendizagem. O problema que é simples acabou tomando um rumo 
diferente do previsto. Enquanto o professor orientador pensava em utilizar os termômetros do laboratório, os alunos deram a ideia de construir um termômetro digital. Como todos os componentes da célula faziam o curso de eletrônica, eles se debruçaram sobre projetos de termômetros digitais que poderiam ser construídos com termistores.

Um dos alunos se prontificou a construir o termômetro. Cabe ressaltar que tanto esse aluno quanto os outros envolvidos no grupo eram do curso técnico de eletrônica, e a maneira encontrada por ele de conectar o curso ao projeto foi construindo um dispositivo eletrônico para medir a temperatura da água no aquecedor. Dessa forma, para construir o termômetro, o aluno utilizou seus conhecimentos de eletrônica e pediu ajuda aos professores nas etapas em que ainda não tinha conhecimentos suficientes.

\section{Astronomia}

Outro ponto que necessitavam verificar durante a instalação era a posição em que deveriam colocar o aquecedor em relação ao sol. Durante a visita à casa solar do CEPEL, o engenheiro que guiou a visita conversou sobre diversos problemas relativos a captação de energia solar. Dentre eles, havia o fato que os coletores deveriam ser posicionados sob a órbita aparente do Sol durante o dia. Explicou também que a inclinação do Sol variava ao longo do ano. O mês no qual foi realizado o teste foi Outubro, mês em que a inclinação da eclíptica está em processo de ascensão. Seria preciso encontrar um lugar ótimo que pudesse ter a maior incidência de luz solar ao longo de todo o dia. A piscina da escola foi escolhida e foi dado aos coletores uma inclinação que permitisse melhor captar a luz solar.

Esse fato foi importante para que os alunos pudessem perceber que o conhecimento astronômico, muitas vezes considerado desprezível na solução de problemas terrestres, fosse entendido de uma nova forma.

\section{A organização da célula}

No decorrer de todo o projeto, além dos conceitos físicos adquiridos, procuramos avaliar como os alunos se organizavam nas células e como interagiam uns com os outros. Observamos, então, que durante os encontros iniciais todos se mostraram corresponsáveis pelo processo. Na etapa de construção do aquecedor, um aluno procurou orientar o restante do grupo quando não sabiam o passo a seguir. Contudo, de forma interessante, ele não dava ordens, mas colocava os colegas para refletirem sobre o motivo daquele passo seguinte, o porquê do uso de dado materi- 
al e não de outro, entre diversos direcionamentos. Esse tipo de participação no projeto foi muito positiva, pois ajudou a evitar o trabalho mecânico e sem sentido na fase da construção, além de contribuir para que os alunos pudessem compreender o funcionamento do coletor solar.

Assim, durante a construção dos dois protótipos, os alunos procuraram um local na escola em que poderia ser instalado o coletor para a verificação de seu funcionamento e de sua eficiência. Após a observação, verificando a incidência solar ao longo do dia e a facilidade de acesso para fazer as medições necessárias, decidiram pela instalação na piscina do colégio. Logo que autorizada a instalação, começaram a etapa de medições.

Depois de posicionado e instalado o coletor, foi colocada água nas caixas (isopor e galão de 20 litros). A partir desse momento, vários problemas surgiram nas vedações, principalmente nas conexões da caixa de isopor e do galão, o que danificou um dos coletores. Dessa forma, visto que a tarefa agora era solucionar os vazamentos, os alunos testaram vários materiais, porém as providências foram em vão. Eles somente conseguiram solucionar o problema com a ajuda de um funcionário da escola, que indicou um tipo de vedação que poderia ser usada com água nas caixas, de modo que não precisariam desmontar os aquecedores para solucionar os vazamentos.

Como no período do processo de instalação faltavam apenas duas semanas para a EXPOTEC e não havia tempo suficiente para resolver os problemas e realizar os testes, a instalação permitiu apenas a verificação do funcionamento do aquecedor, porém não foi possível verificar a eficiência dos mesmos.

Após a apresentação do equipamento na EXPOTEC, então, pode-se perceber a necessidade de uma reinstalação dos aquecedores. Assim, como não tiveram o resultado da eficiência dos coletores, eles resolveram utilizar esse dado a favor do Projeto, fazendo uma enquete para saber a opinião das pessoas sobre o aparato durante a exposição e, depois, divulgarem os resultados experimentais no blog.

Portanto, a apresentação do Projeto na Expotec foi um dos maiores motivadores durante todo o processo. Nesta etapa, o grupo pôde mostrar os aquecedores - prata e preto - e o termômetro digital, explicar o funcionamento de ambos e apresentar todo o processo do trabalho. Os alunos também aproveitaram para divulgar o blog por meio de um panfleto de divulgação. E, como dito anteriormente, realizaram uma enquete onde puderam saber a opinião dos visitantes sobre qual dos aquecedores seria o mais eficiente, o coletor com as caixas pintadas de preto ou o coletor com a parte metálica das caixas de leite longa vida. $\mathrm{O}$ resultado da 
enquete, então, foi divulgado no blog, assim como o resultado experimental feito após o evento.

Após a apresentação do projeto, os alunos voltaram para os trabalhos a fim de verificar a eficiência dos aquecedores. Antes da reinstalação dos coletores, foi preciso fazer alguns ajustes e algumas reflexões. Um ponto bem interessante indicado pelos alunos foi a utilização de caixas d'água diferentes (caixa de isopor de 50 litros e galão de 20 litros), pelo fato de o galão ser transparente e menor, os alunos não poderiam afirmar se o aquecimento da água era devido à placa do aquecedor ou diretamente da exposição do recipiente ao sol. Além dessa questão, antes da Expotec observamos que os canos estavam colocados na posição invertida, ou seja, a entrada d'água estava na posição da saída e a saída na posição da entrada.

Para facilitar os testes, os alunos sugeriram a utilização de recipientes iguais para as caixas d'água, decidindo usar duas caixas de isopor de 50 litros.

Nos momentos seguintes, do $27^{\circ}$ ao $29^{\circ}$ encontro, trabalhamos nos reparos do coletor danificado, na reinstalação dos aquecedores e na verificação da eficiência deles. Para o teste de eficiência foram realizadas medidas de temperatura ao longo do dia durante uma semana. Assim, após a reinstalação e a verificação da eficiência dos aquecedores, no $31^{\circ}$ encontro, fizemos uma reunião final baseada na técnica do grupo focal.

\section{Avaliação através de um grupo focal}

Para finalizar o projeto utilizamos no último encontro a técnica do grupo focal (DIAS, 2000; GOMES; BARBOSA,1999; NETO; MOREIRA; SUCENA, 2002; MACEDO, 2006). Planejamos o debate de modo a avaliar o projeto, refletir sobre a atividade experimental investigativa (construção do aquecedor solar) e enriquecer a pesquisa etnográfica. Os alunos foram reunidos num círculo e foram colocadas questões sobre o processo pelo qual haviam passado. Para facilitar sua identificação, procuramos classifica-los pela letra $\mathrm{C}$ da célula (as outras duas, $\mathrm{A}$ e $\mathrm{B}$, desistiram) e por um número que os identificaria dentro da célula.

Analisando as falas e o comportamento do grupo, classificamos essas falas em alguns tópicos:

- Avaliação do projeto, quando identificamos que ampliaram seus conhecimentos em relação a fontes de energias, que as visitas foram interessantes e ajudaram bastante na aquisição de conhecimentos e que a participação na feira tecnológica os ensinou a se organizarem e a pesquisarem. 
- Participação e Permanência no projeto, quando os alunos destacaram que um dos fatores que incentivaram a permanência até o fim do projeto foi a oportunidade de participar de uma feira tecnológica (Expotec). Como os alunos envolvidos estavam na $1^{a}$ série do Ensino Médio, sendo o primeiro ano no CEFET-RJ, a feira foi a primeira do grupo. Além de expor o trabalho, eles queriam ver o produto final e o funcionamento do aquecedor solar, motivo pelo o qual, também, não desistiram do Projeto. Alguns ainda destacaram que o gosto pela Física e a relação de amizade estabelecida no grupo foram um dos fatores que os levaram a participar e permanecer no projeto até o fim.

- Dificuldades, pois no início do projeto os alunos destacaram que tinham vergonha de expor suas opiniões por não conhecerem o professor orientador, o que dificultou os debates iniciais. $\mathrm{O}$ fato de não respondermos às questões e sempre deixarmos que chegassem às respostas por si mesmo foi um ponto ruim detectado pelos alunos, pois afirmaram que acabavam esquecendo de pesquisar as questões em casa. A extensão do projeto foi outra dificuldade apontada pelo grupo.

- Ligação entre os debates iniciais e a construção e instalação do aquecedor, visto que, inicialmente, acharam que esses pontos não tinham nada a ver um com o outro. Os alunos estavam ansiosos para construir o equipamento, mas depois perceberam que era necessário ter base e conhecimento sobre os temas para depois construir o aquecedor. Isso foi exemplificado por C. 1: Se você quer fazer um projeto científico, você primeiro tem que preparar o terreno, colocar aquela ideia na cabeça da pessoa. Para que você vai construir o aquecedor solar? Vou esquentar só água? Não, vou economizar energia, vou reciclar, tirar aquela garrafa que está jogada no mar. É muito mais do que pegar energia do Sol e tomar banho quente, é uma questão bem mais ampla.

- Contribuição do projeto, que foi importante, pois ganharam experiência e aprenderam a se organizar melhor. Conforme afirmado por C.2: Sempre que você faz alguma coisa com determinação, tudo volta, tem um retorno, pode não ser agora, mas futuramente.

- Importância dos protótipos, quando identificaram a necessidade de um projeto em pequena escala a fim de detectar problemas e resolvê-los. Caso o aquecedor solar fosse instalado diretamente em uma caixa d'água, seria muito difícil resolver os problemas, como os vazamentos que prejudicaram os canos. Se não tivesse um teste preliminar, o prejuízo e o trabalho seriam maiores. Os alunos destacaram, pois, que os erros e problemas não foram ruins, pois assim puderam aprender e aperfeiçoar seus conhecimentos. 
Dessa forma, as questões trabalhadas durante o projeto devem ser do interesse de todos, mesmos aqueles que não vão seguir carreira científica. $O$ projeto permitiu que cada um, de certa forma, se identificasse como um segmento que gosta, como a divulgação, a computação e a eletrônica. Uma aluna ressaltou, ainda, que a melhor parte do Projeto foi a conscientização que lhe proporcionou, abordado por $\mathrm{C} 3$, como se segue:

C.3: O maior problema das pessoas (quanto a mudar o mundo) é não acreditar que tudo começa com um pequeno passo, nada começa grande, tudo, tudo, começa com uma pequena ação. Eu não posso fazer pelos outros, eu estou fazendo a minha parte.

\section{Conclusão}

A primeira conclusão que deve ser tirada do desenvolvimento dessa pesquisa é que a atual cultura da escola fala mais alto em diversos sentidos. Ausência de uma avaliação formal do trabalho desestimulou muitos alunos. Pode-se dizer que, do grupo inicial, $51,8 \%$ dos alunos desistiram e $48,2 \%$ permaneceram. A criação de uma nova cultura na escola, onde a investigação seja parte fundamental, ainda necessita percorrer um longo caminho. Esse tema deverá ser abordado em outros estudos.

O trabalho com projetos de pesquisa mostrou-se eficiente dentro do grupo que aceitou tomar parte desse processo. As células de inovação possibilitaram uma relação bem harmoniosa entre o professor orientador e os alunos, o que contribuiu na execução e finalização do estudo, permitindo o envolvimento de todos na aprendizagem, no gosto pela investigação, pela Física, além de valorizar o trabalho individual e coletivo.

A estratégia dos projetos de investigação se mostrou eficaz, mesmo com um grupo reduzido de alunos e levando-se em conta que estes não faziam parte da organização do currículo da escola. Conforme destacamos anteriormente, nosso objetivo não foi substituir o ensino tradicional pelos projetos de pesquisa, mas utilizá-los como ferramenta capaz de enriquecer o atual ensino de Física, que, na maioria das vezes, não aborda problemas reais e comuns no dia-dia dos alunos.

O enfoque sobre Natureza da Ciência nesse trabalho estabeleceu um polo motivador, permitindo que os alunos se envolvessem num processo onde o conhecimento estava sendo construído e não apenas recebendo passivamente informações. Além disso, foi possível produzir uma reflexão sobre as atividades executadas, não só no que tange às ações cotidianas, mas sobre suas consequências socio- 
ambientais. A inserção de temas controversos pode proporcionar aos alunos uma imagem mais realista da ciência, desmitificando as falsas ideias de sua suposta neutralidade e infalibilidade.

A atividade experimental investigativa desenvolvida durante o projeto mostrou-se, assim, muito rica, pois os alunos não tinham resultados de antemão e nem um roteiro a seguir durante a construção do coletor solar. Erros e problemas surgiram, mas foram importantes durante o entendimento do funcionamento do aquecedor. A atividade investigativa contribuiu, dessa forma, não só para a aquisição de conteúdos, mas principalmente para o desenvolvimento da criatividade e reflexão dos alunos.

Durante as discussões do grupo focal foi possível detectar a compressão dos alunos sobre os temas abordados. Um aspecto analisado no decorrer deste trabalho foi a verificação do início de um posicionamento mais reflexivo e crítico em relação aos conteúdos do ensino de ciências. Ao contrário da maioria dos alunos do Ensino Médio que apenas absorve conteúdos científicos, considerados absolutamente verdadeiros para reproduzi-los nas avaliações, estes estudantes começaram a perceber que existem interpretações diferentes para os mesmos fenômenos e fatos.

Portanto, para que se processe uma aprendizagem verdadeira não basta somente assimilar informações, é necessário discuti-las com os colegas, fazendo e recebendo questionamentos, argumentando. Aprendizagem é um ato coletivo. Assim, a construção de um posicionamento crítico é de fundamental importância para a formação de uma sociedade capaz de tomar decisões bem fundamentadas, participando de forma consciente nas decisões e nos rumos da ciência e da tecnologia.

Sendo assim, tentando perceber se os objetivos foram alcançados, analisamos a postura dos alunos durante os debates, no decorrer do projeto de investigação, durante as atividades de experimentação e nas falas durante o grupo focal. Pode-se perceber que houve um significativo desenvolvimento da capacidade de argumentação, de expor suas opiniões, de questionar as opiniões dos outros, e de aceitar e absorver as opiniões dos colegas.

A presença do professor-orientador causou certo constrangimento no início dos debates. Entretanto, ao longo das atividades, o professor-orientador foi sendo aceito como um membro do grupo, que buscava orientar e não julgar o "certo" e o "errado". Nesse sentido, os projetos de pesquisa mostraram-se uma alternativa eficaz não só na aprendizagem científica, mas também de exercício da cidadania. 
Durante o projeto, os alunos tiveram contato com vários aspectos da produção do conhecimento tecnológico, como elaboração de um projeto, seleção dos materiais utilizados, verificação da viabilidade econômica e dos impactos ambientais, construção de um protótipo, instalação, solução dos problemas verificados e teste de eficiência. Mesmo não chegando ao objetivo final da proposta, que era a construção e instalação do produto final em uma casa, colégio ou outra instituição, as etapas intermediárias foram muito ricas, pois permitiram verificar a importância de um projeto em pequena escala. Tais passos seriam inviáveis em um coletor construído em larga escala e instalado em uma caixa d'água convencional. Portanto, o trabalho com as células permitiu a verificação de importantes aspectos da tecnologia e de suas relações com o conhecimento cientifico.

Pode-se destacar que o projeto contribuiu, também, para o posicionamento desses alunos no ensino formal, pois observamos ainda no decorrer deste trabalho de pesquisa que os alunos se tornaram mais participativos e questionadores nas aulas formais de Física.

Para a atuação desse jovem de forma crítica foi fundamental o diálogo. Isso só foi possível porque tanto o professor-orientador como os alunos puderam discutir livremente sobre os problemas. É de suma importância que haja envolvimento e respeito de ambas as partes e não imposição de ideias por meio do professor-orientador. Procurou-se assumir durante o estudo uma postura nesse sentido, mediando os debates e orientando o processo de aprendizagem. Esse caminho possibilitou um posicionamento dos alunos frente aos problemas trabalhados. Todos, de certa forma, se mostraram corresponsáveis pelo processo.

$\mathrm{O}$ envolvimento dos alunos com problemas reais permitiu que eles verificassem seu importante papel na sociedade, como foi verificado no grupo focal. Os alunos mostraram-se responsáveis por suas ações e acreditaram que as mudanças começam com atitudes pequenas e coletivas.

Entretanto, verificar se a participação neste projeto contribuiu de alguma forma para a atuação desse jovem nas decisões acerca da Ciência e da Tecnologia é um tanto quanto prematuro. Porém, acreditamos que foi um primeiro passo para que os alunos refletissem sobre esses pontos. O conhecimento e o esclarecimento das questões acerca do aquecimento global, das fontes de energia limpa e do problema do lixo produziram nos alunos um discurso consciente. As ações futuras na intenção de solucionar tais problemas não puderam ser avaliadas. Mas acreditamos que possam vir a dar frutos.

O papel do professor-orientador do grupo foi o de apenas incentivo e orientação, não apresentando um roteiro e uma resposta pronta, sempre incentivando a pesquisa. Esse fato foi bem aceito pelos estudantes que permaneceram durante 
todo o projeto. Com isso, percebeu-se que o grupo reagiu bem à quebra de outro fator da cultura escolar, aquele que vê no professor como sendo a pessoa que determina o que é certo ou errado.

Além das intervenções concretas, o projeto permitiu um maior conhecimento da situação apresentada e uma reflexão da atividade desenvolvida. No final, os alunos puderam apresentar o projeto tanto para demais alunos da escola como para a comunidade, podendo, assim, divulgar o projeto.

Mesmo sem poder avaliar as consequências deste projeto no futuro, verificamos que foi possível construir um conhecimento sobre os temas nesse primeiro contato. Para que esta experiência possa apresentar resultados mais concretos é necessário que ela seja expandida para toda a formação.

Por último, uma das consequências positivas dessa experiência didática foi a decisão do CEFET/RJ em adotar o Ensino Integrado a partir de 2013. As dificuldades apresentadas em termos de tempo livre para o desenvolvimento de projetos de investigação foram relatadas à comissão que discutia a adoção do novo formato de ensino. Isso levou a comissão e a direção a adotarem um modelo onde as aulas tradicionais (integradas do Ensino Médio e Técnico) fossem reduzidas e condensadas num único turno. Com isso, os alunos passaram a dispor do outro turno para o desenvolvimento de projetos de investigação.

Acredita-se que essas atividades de investigação possam vir a ser parte fundamental da formação de técnicos de nível médio. O moderno mundo do trabalho não concebe mais o trabalho técnico sem investigação e inovação.

\section{Referências}

ABN-EL-KHALICK, F. Teaching with and about nature of science, and science teacher knowledge domains. Science \& Education, v. 22, p. 2087-2107, 2013.

ALANO, J. A. Manual sobre a construção do aquecedor solar com descartáveis. Disponível em:

$<$ http://josealcinoalano.vilabol.uol.com.br/manual/manual.pdf>. Acesso em: 01 maio 2010.

AMERICAN ASSOCIATION FOR THE ADVANCEMENT OF SCIENCIE: 1989. Science for All Americans. AAAS, Washington. Chapter 3: The Nature of Technology. Disponível em:

$<$ http://www.project2061.org/publications/sfaa/online/chap3.htm>. Acesso em: ago. 2010. 
ANDRÉ, M. E. D. A. Etnografia da prática escolar. 17. ed. Campinas: Papirus, 2010 .

ANDRÉ, M. E. D. A. Estudo de caso em pesquisa e avaliação educacional. Brasília: Líder Livro Editora, 2008.

ARAÚJO, M. S. T. D.; ABIB, M. L. V. D. S. Atividades experimentais no ensino de Física: diferentes enfoques, diferentes finalidades. Revista Brasileira de Ensino de Física, v. 25, n. 2, jun. 2003.

AULER, D.; DELIZOICOV, D. Alfabetização científico-tecnológica para quê? ENSAIO - Pesquisa em Educação e Ciências, v. 3, n. 1, jun. 2001.

BORGES, A. T. Novos rumos para o laboratório escolar de Ciências. Caderno Brasileiro de Ensino de Física, v. 19, n. 3, p. 9-30, 2002.

DIAS, C. A. Grupo Focal: técnica de coleta de dados em pesquisas qualitativa. Informação \& Sociedade: Estudos, v. 10, n. 2, 2000.

GIL PÉREZ, D.; VALDÉS CASTRO, P. La orientación de las prácticas de laboratorio como investigación: um ejemplo ilustrativo. Ensenãnza de las Ciencias, v. 14, n. 2, p. 155-163, 1996.

GOMES, M. E. S.; BARBOSA, E. F. A técnica de Grupos Focais para obtenção de dados qualitativos. EUCATIVA (Instituto de Pesquisas e Inovações Educacionais), fev. 1999.

GORE, A. Uma verdade inconveniente: um aviso global. (DVD-Vídeo). Direção de Davis Guggenheim. EUA, 2006. 1 DVD, 96 min, documentário.

HERNANDES, C. C.; CLEMENT, L.; TERRAZZAN, E. A. Uma atividade experimental investigativa de roteiro aberto partindo de situações do cotidiano. In: ENCONTRO DE PESQUISA EM ENSINO DE FÍSICA, VIII, 2002, Águas de Lindóia. Atas... Disponível em:

$<$ http://www.sbf1.sbfisica.org.br/eventos/epef/viii/PDFs/PA1_13.pdf $>$. Acesso em: 01 jun. 2011.

HERNÁNDEZ, F. Transgressão e mudança na educação: os projetos de trabalho. Porto Alegre: Artmed, 1998. 
HERNÁNDEZ, F.; VENTURA, M. A organização do currículo por Projetos de Trabalho. 5. ed. Porto Alegre: Artmed, 1998.

IRZIK, G.; NOLA, R. A family resemblance approach to the nature of science for Science Education. Science \& Education, v. 20, p. 591-607, 2011.

JULIO, J. M.; VAZ, A. D. M. Grupos de alunos como grupos de trabalho: um estudo sobre atividades de investigação. Revista Brasileira de Pesquisa em Educação em Ciências, v. 7, n. 2, 2007. ISSN 1806-5104.

JULIO, J. M.; VAZ, A. M. Grupos de alunos como grupos de trabalho: Análise e avaliação de atividades de investigação escolar em Física. In: ENCONTRO NACIONAL DE PESQUISA EM ENSINO DE FÍSICA, IX, 2004. Disponível em: $<$ http://www.sbf1.sbfisica.org.br/eventos/epef/ix/sys/resumos/T0205-1.pdf $>$. Acesso em: 01 ago. 2011.

MACEDO, R. S. Etnopesquisa crítica, etnopesquisa-formação. Brasília: Líder Livro Editora, 2006.

MARTINS, J. S. O trabalho com projetos de pesquisa. 6. ed. Campinas: Papirus, 2009.

NETO, O. C.; MOREIRA, M. R.; SUCENA, L. F. M. Grupos focais e pesquisa social qualitativa: o debate orientado como técnica de investigação. In: ENCONTRO DA ASSOCIAÇÃO BRASILEIRA DE ESTUDOS POPULACIONAIS, XIII, 2002, Ouro Preto.

PRAIA, J.; GIL-PÉREZ, D.; VILCHES, A. O papel da Natureza da Ciência na educação para a cidadania. Ciência \& Educação, v. 13, p. 141-156, 2007. 